\title{
The Norm Prohibiting the Chewing of Coca Leaf: From the International System to the Colombian State
}

JULIÁN FERNÁNDEZ*

Article Received: October 17, 2016

Article Accepted: March 30, 2017

Doi: http://dx.doi.org/10.12804/revistas.urosario.edu.co/desafios/a.5228

To cite this article: Fernández, J. (2017). The Norm Prohibiting the Chewing of Coca Leaf: From the International System to the Colombian State. Desafíos 29(2), 61-83. doi: http:/ / dx.doi.org/10.12804/revistas.urosario.edu.co/desafios/a.5228

\begin{abstract}
This article deals with the process of adopting international drug treaties in conformity with the Colombian legal system. International law establishes that substances that are considered illicit, including coca leaf, have legal uses exclusively for medical or scientific purposes. Consequently, the chewing of coca leaf by indigenous communities in the Andean States is mandated to disappear. The Colombian state has signed and ratified these international treaties, and has an obligation to respect its international commitments. Being a pluricultural nation with two formal and equal legal systems (indigenous and ordinary jurisdiction) and with the increased participation of native communities in Colombian politics, the task of implementing this obligation gives rise to a legal conundrum. The Colombian state faces two mutually exclusive obligations: One to its international commitments and another to respect the rights of indigenous communities.
\end{abstract}

Keywords: Indigenous rights, sociology of norms, drug policy

* PhD Candidate in Political Science, European Center of Sociology and Political Science, University of Paris 1 Panthéon-Sorbonne, Paris, France, Email: julianandresfernandez@ gmail.com. http://orcid.org/0000-0001-6594-2101 


\title{
La norma que prohíbe la masticación de la hoja de coca: del sistema internacional al Estado colombiano
}

\begin{abstract}
Resumen
Este artículo trata sobre el proceso de adopción de los tratados internacionales de drogas en el orden juridico interno colombiano. La ley internacional establece que los únicos usos lícitos para las substancias que son objeto de vigilancia, como es el caso de la hoja de coca, son los medicinales y científicos. Por lo tanto, la masticación de hoja de coca realizada por las comunidades indígenas andinas debe ser eliminada. El Estado colombiano ha firmado y ratificado estos tratados internacionales y tiene la responsabilidad de respetar sus compromisos internacionales. Sin embargo, siendo una nación multicultural con dos sistemas formales e igualitarios de derecho (el indigena y la jurisdicción ordinaria) y con el incremento de la participación de las comunidades indígenas en la política colombiana la tarea produce una confrontación. El Estado colombiano se encuentra frente a un dilema: por un lado, cumplir con sus obligaciones juridicas internacionales y por el otro respetar los derechos de las comunidades indígenas.
\end{abstract}

Palabras clave: derechos pueblos indigenas, sociología de normas, politicas de drogas

\section{A norma que proíbe a mastigação da folha de coca: do sistema internacional ao Estado colombiano}

\begin{abstract}
Resumo
Este artigo trata sobre o processo de adoção dos tratados internacionais de drogas na ordem jurídica interna colombiana. A lei internacional estabelece que os únicos usos lícitos para as substâncias que são objeto de vigilância, como é o caso da folha de coca, são os medicinais e cientificos. Portanto, a mastigação de folh a de coca realizada pelas comunidades indígenas andinas deve ser eliminada. O Estado colombiano tem assinado e ratificado estes tratados internacionais e tem a responsabilidade de respeitar os seus compromissos internacionais. No entanto, sendo uma nação multicultural com dois sistemas formais e igualitários de direito (o indígena e a jurisdição ordinária) e
\end{abstract}


com o incremento da participação das comunidades indigenas na política colombiana a tarefa produz uma confrontação. O Estado colombiano encontra-se frente a um dilema: por um lado cumprir com as suas obrigações jurídicas internacionais e pelo outro respeitar os direitos das comunidades indigenas.

Palavras-chave: direitos povos indígenas, Sociologia de normas, Politicas de drogas

\section{Introduction}

August 7, 2012 was inauguration day for Colombian President Juan Manuel Santos. In an unprecedented event for the country, the events of the day began on the peaks of the Sierra Nevada de Santa Marta mountain range with a visit by the new head of state to the mamosthe spiritual leaders - of the Kogi and Arhuaco indigenous peoples. In keeping with their traditions, the natives chewed a mixture of coca leaves and an alkaline solution as they spoke to the new president. This activity is a critical element in our research. Indeed, under international law, coca leaf must be used only for medicinal or scientific purposes; any other use is considered deviant and strongly prohibited. Thus the natives were violating treaties signed by the Colombian state. The native tradition of coca consumption, however, did not seem to embody illegality in the eyes of the president or his delegation.

Since the 1961 Convention on Narcotic Drugs, coca leaf has been classified as one of the most strictly controlled substances. The coca plant is distinguished from other substances, in the sense that it has been used for centuries by many indigenous Andean communities as a source of energy on long work days and for medicinal and religious purposes. These uses are not contemplated within the text of the Convention.

In fact, the authors of the 1961 Convention on Narcotic Drugs, following the conclusion of the report of the Commission for the Study of Coca Leaf set up in May 1950, explicitly required signatory States to abolish the chewing of coca leaf within twenty five years of the treaty's entry into force. This took place in 1964, making 1989 the deadline to eradicate the traditional chewing of coca leaf among members of indigenous cultures. Signatory States were required to 
implement public policies to fulfill their treaty obligations and eliminate this ancestral indigenous practice, a goal that was not achieved. On the contrary, the increasing participation of indigenous communities in Colombia's political life led to a social movement aiming to explicitly extend the legal use of coca leaf to include traditional native practices.

We are also particularly interested in the 1988 United Nations Convention Against Illicit Traffic in Narcotics Drugs and Psychotropic Substances reached to provide States with more tools to fight the increasing drug trafficking of the 1980s. Its main points included the struggle against money laundering, reforming extradition policies, and allowing for the confiscation of property. An article declaring respect for native traditions was incorporated into the 1988 Convention within the historical context of strict provisions to fight the illicit use of drugs.

Although the international framework for drug control, which is the object of our study, refers to the prohibition of coca leaf chewing, our understanding of the international drug control regime must go further than the act of chewing coca. For Andean natives to chew coca, a preliminary process must have taken place: the coca had to be planted, harvested, dried, and often transported. We must understand these steps in the context of the international drug law.

This paper's conceptual framework is based on International Relations Theory (IRT). More precisely, we are concerned with the constructivist approaches in which a norm is considered as a "collective agreement on appropriate behavior, which leads to both changes in identities and interests" (Risse \& Sikkink, 1999, p. 194) and for it to be qualified as international, it must be based on a problem of a transnational nature. In our case: drug control. Reviewing the literature, one finds that Acharya (2004) divided the diffusion of ideas and norms into two broad categories. The first category focuses primarily on the international level and norms considered universal. The principal actors who propagate these types of norms are transnational. They may be moral entrepreneurs, international institutions, or epistemic 
communities. Norms become internalized by international institutions that teach new behaviors to the States (Finnemore, 1993). However, the role of national agents in the adaptation of international norms is disregarded, and a dichotomy is created between the right international norm and the poor local norms. The second category regards the role of local agents and the congruence that may exist between international and local norms. Different concepts are brought to the discussion to understand the process of internalization: cultural organization, the degree of institutionalization, and cultural match (Checkel, 1999). The monitoring of the norm after it has been incorporated, however, does not seem to be a primary concern.

We believe that the prohibition of coca leaf chewing provides an opportunity to analyze the adoption of a norm, considering not only the precise historical moment in which it is established, but also the norm's reconstruction over time within the adopting State. To examine how the prohibition of coca leaf in Colombia has evolved, we will rely on different theoretical approaches that can be applied at precise historical moments, but are later confronted with the conceptual reconstruction that takes place within the State. In the international arena, the prohibition of coca leaf chewing has been in force for more than 50 years without any change, but this stability in the international system is not necessarily reflected within the States. The State can be easily reconfigured as a result of domestic tensions or the capacity of local agents to modify a norm, while at the international level, the consensus to modify a prohibition requires the mobilization of a large number of units, which, in the case of coca leaf, include a limited number of countries with populations that use coca, including Peru, Bolivia, Colombia, and Argentina.

The Colombian case has some characteristics that differ from those of the other countries with native communities that use coca leaf. Unlike Bolivia and Peru, Colombia has a small indigenous population; only around $2 \%$ to $3 \%$ of the total population is of native origin. This small percentage might lead us to think that the adoption of the international prohibition of coca leaf would not meet with great resistance from local actors. The 1991 Colombian Constitution, how- 
ever, grants indigenous peoples the right to self-determination. This means that they enjoy autonomy with respect to political, economic, religious, and legal issues within their designated territories. This gives them the legal basis to demand the reformulation of international norms that affect their traditions, including norms affecting the use of coca leaf. Not all of Colombia's native communities traditionally use coca leaf, however. We have chosen to work in this article with the Nasa people, in the department of Cauca. They have, in fact, been one of the most belligerent groups since the Spanish colonization, and they have been fighting to preserve the traditional use of coca leaf. They were also the founders of Colombia's national indigenous associations.

This text is divided into two sections. In the first, it deals with our understanding of how the prohibition of coca leaf chewing in the international system was constructed. We want to reconstruct the origins of the law by identifying the key actors with fundamental roles in the prohibitionist approach and in the construction of the binding legal mechanisms that have been put in place to preserve the continuity of the prohibition (Bewley-Taylor, 2001; Dudouet, 2009). The second section addresses the way in which the international norm is adopted in the Colombian legal system. The Colombian case integrates the concept of multicultural societies into the sociology of norms, with the added particularity of having more than one legal system. Conflicts between traditional indigenous uses of coca and the failure of public policy against drugs have led some Colombian non-state actors to advocate expanding the legal use of coca leaf beyond medicine and science, allowing for a reconstruction of the norm within Colombian law. 


\section{The construction of the coca leaf chewing prohibition in the international system}

\section{The 1961 Convention: beginning of the prohibition}

Why does a practice that is mainly restricted to three Andean countries become a subject of international concern? To try to answer this question, we rely on the framework of IRT in which a norm is qualified as international if it is built around a problem with transnational reach. Ethan Nadelmann (1990) addresses the topic of internationalization by analyzing global prohibition regimes. He demonstrates that certain behaviors such as incest, which deeply shock certain societies, are not necessarily matters of international interest, and the regulation of such matters continues to be domestic. Once an undesirable behavior goes beyond the capacity of the State to control it, however, it becomes the subject of an international regime.

Indeed, one of the most internationalized issues is that of drugs: pharmaceutical companies, international drug control institutions, and international criminal networks are just some of the actors involved. To establish a normative structure for drug policies, several international treaties have been agreed upon.

International conventions on narcotic drugs have been issued beginning from the historical juncture marked by the Opium Wars of the late nineteenth century that established the image of a drug user as someone devoid of will due to his or her narcotics addiction.

The stereotype of drug users recalls the image of Chinese men devastated by smoking opium. This stereotype was largely disseminated and defended by a moralizing discourse, led mainly by Protestant North Americans (Dudouet, 2009; Bewley-Taylor, 2001).

Similarly, in Phantastica, a medical work written by Dr. Louis Lewin in 1924, the image of the coca leaf user was built around the representation of a malnourished and emaciated individual with an irrepressible desire to consume the drug: 
Physically and morally they behave like opium smokers. A cachectic state appears with extreme emaciation accompanied by a gradual change of demeanour. They are old men before they are adults. They are apathetic, useless for all the most serious aspects of life, subject to hallucinations, and solely governed by the one passionate desire for the drug, besides which everything else in life is of inferior value (Lewin, 1998/1924, p. 68).

This duality between the bad drug user and the good non-user bring us back to a concept studied by researchers from the constructivist school in IR that references what is called moral cosmopolitanism (Acharya, 2004). Here, the key players are moral entrepreneurs who seek to change behaviors that profoundly disturb them. To modify the state of things, the moral entrepreneur seeks to organize a legally-binding international system. He also aims to establish international institutions that both teach good behaviors (Finnemore, 1993) to States and on the other hand, coerce States to fulfill their international legal commitments.

In this paper we are concerned mainly with the 1961 Convention. Article 4 Section c) of this Treaty established that substances subject to control must be used exclusively for medicine or science, and identifies coca leaf as a very dangerous substance. One of the reasons for this is that it contains the active element in cocaine, and it is a relatively simple process to extract the alkaloid. In Article 49 section e), the Convention also establishes that coca leaf chewing must be abolished within twenty-five years of the treaty's entry into force. But how can we explain the existence of an article in the treaty for the specific purpose of prohibiting the chewing of coca leaf? To answer this question, we trace the history of the Commission to study coca leaf.

\section{The Commission of Enquiry on the Coca Leaf}

On April 22, 1947, Carlos Holguin Lavalle, who was then the Permanent Delegate of Peru to the United Nations, communicated to the Commission on Narcotic Drugs that the Peruvian government 
had considered certain elements: 1 ) that the native population living in Andean mountains and valleys had been chewing coca leaf from time immemorial; 2) that cocaine was extracted from this plant; and 3) that opinions were widely divergent as to whether this practice was harmless or had disastrous biological, social, and economic effects on the indigenous people (Nations Unies, 1950, p. 3). These questions were important to the Peruvian government, which subsequently asked the Commission to create a committee of experts to conduct a site survey and determine the following:

a) the harmful or harmless effects of the coca leaf chewing habit upon the human body in general or upon one specific organ in particular; b) the factors or motives (i.e., climate, high altitude, diet, organic reserves, heredity, tradition, etc.) that prompt this chewing habit; c) the social and economic implications of the aforesaid habit; and d) the measures to be taken, if this habit proves to be harmful, in order to eradicate it from the population concerned (Nations Unies, 1950, p. 3).

On August 10, 1948, the Peruvian Government's request was accepted. A Commission with four members was established, consisting of two medical experts and two experts in the management of drug control issues. The two medical experts were Verzar Frederick of Hungary and Alfred Marcel Granier-Doyeaux of Venezuela. The two policy management experts were Jean-Philippe Razet, director of the French Bureau of Narcotics and Howard Fonda of the United States, who presided over the Commission. Fonda was the vice president of the American Pharmaceutical Manufacturers Association, a highly-respected banker, and president of the of the Chamber of Commerce in the town of Yonkers, New York. It should be noted that in the construction of the drug control system, one of the entities most interested in monopolizing the extraction of narcotics was the pharmaceutical industry, and the participation of Fonda in the process was therefore not considered to be disinterested.

The native communities studied by the Commission were the Quechua and Aymara people of Peru and Bolivia. The methodology used 
for the report was primarily to gather information from central and local government authorities, the military, medical personnel, pharmacologists, scholars, workers, religious leaders, and representatives of public opinion interested in the problem of coca leaf. Ironically, no information was gathered from indigenous communities. The subjects of the research had been completely ignored!

The report has five parts. Part One is a description of the living conditions of coca leaf consumers. Consuming coca leaf is frequently related to the poor conditions in which natives lived, as well as to their low educational level; their intelligence level is described as below normal. The second part deals with some medical considerations regarding the effects of chewing coca leaf such as: the modes of consumption, the amounts used, the effect of coca on fatigue, hunger, and its relation to living at high altitudes. Several local health practitioners speak very negatively about coca leaf chewing. A doctor from Cochabamba says: "the mental decay and social inferiority of the Indian are due to: a) lack of education; and b) the influence of two toxic substances, i.e. coca leaf and alcohol" (Nations Unies, 1950, p. 29).

Similarly, Dr. Juan Manuel Balcázar, the Bolivian Minister of Hygiene and Safety, states that:

The native who does not consume coca is keener, more intelligent and of a happier disposition; he is more willing to work, more vigorous, and has greater resistance to disease. He is more inclined to join in the progressive movements of the country... the coca addict is abulic, apathetic, lazy, insensitive to his environment (Nations Unies, 1950, pp. 121-122).

Moreover, the native is described as someone who needs protection. The use of coca leaf as a means for indigenous workers to provide themselves with energy is explained in the report as a form of oppression by mining company owners, who thought only of their own benefit when they said that "a worker who chewed coca leaf had a higher output since he could work longer without eating" (Nations 
Unies, 1950, p.56). Following the logic of treating the natives as children, it is also said that the making of the chique - a ball made from coca leaf for chewing - took them a lot of time, which they could use to work. Finally, the report concluded that "from the social standpoint the effects of chewing coca leaf are highly prejudicial both to the individual and to the nation" (Nations Unies, 1950, p. 59)

The Commission established that coca leaf chewing was a habit rather than an addiction, and could therefore be easily ended. It also recommended creating an institution to monitor the progress of limiting consumption, which must take place gradually.

Coca leaf is prohibited in article 49 of the 1961 treaty. From this point forward, the signatory states were committed to implementing public policies to eliminate the native tradition.

\section{The process of adapting the prohibition to Colombia}

Colombia has a very small indigenous population, making up about only three to four percent of the total population. One point is fundamental, however: the natives have their own special jurisdiction under the 1991 Constitution. This means that within their designated territories they exercise judicial, cultural, and economic autonomy. The recognition of their rights is intrinsically linked to the reconfiguration of the international prohibition of coca leaf chewing within the territory of the Colombian State.

According to the Colombian National Indigenous Organization (Organización Nacional Indigena de Colombia - ONIC), there are 102 separate indigenous peoples in the country. Most of these peoples live in the western part of the country, in the Amazon region, in the mountains of the Sierra Nevada de Santa Marta, and in the northern department of Guajira. Not all of them use coca leaf.

In this paper, we will primarily discuss the community called the Nasa. The Nasa inhabit the department of Cauca in southwestern Colombia, 
and they are one of the country's largest indigenous groups. The Nasa people were the primary initiators of the Colombian indigenous social movement, established to demand respect for the identities, cultures, and territories of the indigenous population. The department of Cauca contains one of the largest indigenous populations of Colombia and has a special cultural link to the use of coca leaf.

\section{The Socio-cultural context of coca chewing in Colombia before the 1961 Convention}

The department of Cauca is in southwestern Colombia. Its capital, Popayán, was one of the main political centers in the nineteenth and early twentieth centuries, along with Cartagena and Santa Fe de Bogotá. Cauca has two important features related to our subject: the first is that around twenty percent of the population is of indigenous origin, and the second is that as a traditional power center, it was home to a social class of aristocrats and large landowners.

From the time of the Spanish conquest, and continuing even into the middle of the twentieth century, the dominant class in Cauca, particularly the large landowners, obligated natives to work for them and paid them with coca leaf (Garcia, 2007).

While natives could still be paid with coca leaf, however, some voices of Popayán's political and economic elite actively protested against the practice. Gerardo Bonilla Iragorri, for example, a physician and member of one of the most influential families in the city, wrote a book in 1945 called The consumption of coca in the department of Cauca (2010/1945). In his text, Iragorri criticizes the fact that: "the landowners and the wealthy population of Cauca pay their workers and farmers with miserable wages and even worse, the payment of wages with coca leaf" (p.428). Furthermore, Bonilla Iragorri was an strong critic of coca leaf chewing. Anti-coca reports by Bonilla Iragorri were processed by Dr. Jorge Bejarano in 1920, who was then a professor of Public Health at the National University in Bogotá. After a recognized career as a scholar, Bejarano became increasingly involved in politics. He was a member of the Liberal Party and served on the 
Bogota City Council and in Congress. In 1947, he was appointed Minister of Health. Bejarano was also strongly opposed to the chewing of coca leaf, referring in the journal America Indigena in 1945 to the damage that natives caused themselves by chewing:

To the physical degeneration must also be added the moral implications: crime is high among these individuals. It seems that their minds only obey the force of instinct, and deceit, which is one of their sharpest features, is probably the effect of psychological imbalance due to the habitual use of coca (p. 307).

According to Bejarano, the consumption of coca leaf was a public problem that could start affecting the rest of the population. He asked the Academy of Medicine to use its influence to act on this issue and proposed "to request that we completely destroy the coca plantations by paying compensation to owners or replacing the ancient cultures with crops that can be used for food" (Nations Unies, 1950, p. 309).

This moment is very important in our case study because the prohibition of chewing was initiated. According to the Commission on Narcotic Drugs, in 1946 the Colombian government responded to the investigation of coca leaf, saying:

a) the Government of Colombia holds the chewing of coca leaf to be harmful; b) There is a close but not exclusive relationship between diet and chewing; for the moment, it causes extreme nutritional deficiency; c) the total removal of the coca is an economic struggle because the owners (landlords) pay much of the wages of their laborers in coca leaves...; the natives of certain areas of the department of Cauca applauded the government policy of suppression and proposed replacing coca cultivation with banana, corn, cassava, sugar cane, rice, and cacao (Nations Unies, 1950, p. 112).

From this time on, there was a series of decrees to initiate the prohibition of coca leaf chewing. Since we seek to understand how the prohibition passed from the international system to the domestic 
framework, we wanted access to communications deployed by the international narcotics control agencies to exert pressure on the Colombian government to institute policies for eradicating the illegal uses of coca leaf. In this regard, we sought and found, in the Colombian national archives, communications between the Colombian government and international narcotics control institutions regarding the uses of coca leaf. These documents dated from before 1970, and we were particularly interested in communications regarding the 1961 Convention. In a communication dated 13 July 1965, for example, the Permanent Central Opium Board, the international drug control institution that was later renamed the International Narcotics Control Body, asked the Colombian government to submit "the forecasts of the amount of coca leaves that will be used in 1966 for chewing and the amount of coca leaves that will be stored for the same purpose on 31 December 1966" (Lande, 1965).

In its response to this request, the Colombian government claimed that:

In accordance with the provisions on trade and drug control in Colombia, coca leaf cannot be legalized for chewing needs because currently, according to the information provided by the health authorities of the departments of Cauca and Huila, all coca leaf must be confiscated and the plantations destroyed. Furthermore, the use of coca leaf for pharmaceutical products is not justified because the pharmacopoeia has eliminated this drug as a medicine (Tellez, 1965).

We also sought access to contemporary communications between the international organizations and the Colombian government around the issue of chewing, but we did not find any official documentation related to this problem. Nonetheless, when an indigenous group produced and marketed a soft drink containing coca leaf, Camilo Uribe - a former member of the International Narcotics Control Board - told Colombian journalists that he would take action to oppose any attempt or initiative to deviate from the exclusively medicinal or scientific use of the leaf by Member States: "Our mandate is very 
clear: to ensure that UN member countries respect the treaties they have ratified." On the issue of eliminating coca leaf chewing, he said: "no Andean country has filed any reservations regarding the [1961] Convention, and their parliaments have ratified it. What fault is it of the INCB if they have signed [without being fully in agreement]?” (Maldonado, 2008).

\section{The integration of the 1961 treaty into the domestic legal framework}

The norm of norms that governed Colombian public life in 1961 was the country's 1886 Constitution. The indigenous peoples were not mentioned in this document and were not considered citizens, or even adults. They were treated as savages who would eventually have to convert to Christianity, abandon their pagan practices, and transition to civilized life. This context presented no obstacles to the domestic adoption of the prohibition of traditional chewing that was imported from the international system and had to be internalized to bring the country into compliance.

The historical context of mid-twentieth century Colombia on coca leaf allows us to be in line with the literature in IR that references what is called cultural match. Checkel (1999) proposes that an international norm spreads faster when it fits with previously established local norms.

The International Convention was not established in the domestic legal order until 1974. The treaty was signed by Colombia in 1972 and then it required Congressional approval to be become law. Once this process was completed, it became Law 13 of 1974, the reference framework for drug control. Wanting to know more about this law, we consulted the Congressional Library for records of the legislative debates that led to its approval.

In the Congressional records, we found that there were no public discussions regarding Article 49 of the 1961 Convention, which prohibits the consumption of coca leaf, even though under international law States that adhere to a treaty can make reservations. A 
reservation enables a State to declare that it has a different interpretation with respect to the scope of an article in the Treaty. Though the Colombian Congress was empowered to make a reservation in the Treaty, however, it did not do so. The international ban on coca leaf chewing was approved for integration into Colombian law without any such reservation.

The documents that we have collected on the process that led to the establishment of Law 13 of 1974 point to an element that provides insight into how political elites use international treaties as a way to consolidate their favored public policies. This mechanism follows a top-down logic; in other words, there is a process of social learning led mainly by the political elite, whose aim is to adopt international norms. Cortell \& Davis (1996) postulate that: "Government officials and societal actors can invoke an international rule to further their own particularistic interests in domestic policy debates. That is, a domestic actor can use the existence of an international rule to justify his own actions or to call into question the legitimacy of another" (p. 453).

This mechanism is reflected in the preamble of the bill, where the Colombian government requested Congress to approve the Convention:

It is necessary to be part of the new global legal organization to be able to use all the mechanisms and benefits that are provided in it, and mainly to organize our national legislation, which is currently in the process of reform, we must avoid dysfunction (with the international order) that would be adverse to the effort to fight against the dangerous behaviors that are the subject of attention of all governments. The study of the norms that form part of the project... will convince the urgency of ratification and the advantage of harmonizing the treaty within our national legal order (Borda, C., \& Salalar, J., 1973).

It must be said that although the Convention was finally established without any participation by native communities, movements for 
indigenous peoples rights took off nationally in the same decade of the 1970s.

\section{The movement for native people's rights and the reformulation of the international norm}

Three decades had already passed since the writings of Bonilla Iragorri and Jorge Bejarano on the chewing of coca leaf. A series of elements began to structure the national indigenous movement in Colombia in the 1970s, a movement whose goal was the recognition of indigenous rights.

The first indigenous organizations, most prominently the Regional Indigenous Council of Cauca (Consejo Regional Indígena del Cauca CRIC) and the National Indigenous Organization of Colombia (Organización Nacional Indigena de Colombia - ONIC), were founded in 1971 and 1972 respectively. These two organizations became the platforms for the mobilization of Colombian indigenous communities.

We will not provide a detailed description of the indigenous mobilization in this article. We are primarily interested in understanding how these mobilizations had an impact on the international norm that prohibits the chewing of coca leaf.

We wanted to identify the moment when the international norm began to be reconstructed. We found the beginning of the process in Article 7 of Law 30 of 1986, known as the Statute on Narcotics. At that time, Colombia was still functioning under the Constitution of 1886, in which indigenous people were considered savages; the 1961 Convention had already been incorporated into domestic law by Law 13 of 1974. However, Article 7 of Law 30 postulated that "The National Council on Narcotics will regulate the crops of plants from which it is possible to extract narcotics and the consumption of these by indigenous people, according to their customs and practices derived from their tradition and culture." 
Article 7 is the beginning of the reconstruction of the international norm in the context of Colombian law. From that point on, the government was obligated to consider the traditional uses of coca leaf in native communities. We have had access, through the Congressional records, to the debate on this law. We sought the participation of indigenous leaders in these debates, as well as the participation by anthropologists or confrontations between political parties. The first thing that we found was that the article had been proposed by the government itself with no explanation. In fact, the debates in the House of Representatives and then in the Senate hardly mention this article of the bill. The only response to the article from the House of Representatives was made by Jesús Edgar Papamija (1985), a representative from the Department of Cauca who sought increased rights for indigenous communities:

Although the Statute is an important and valuable tool in the fight against drug trafficking, which by the way has caused so much damage in the country, it is also true that the blind application (of the treaty) can increase the socio-economic problems and problems of public order in areas such as the department of Cauca. Poor campesinos and indigenous peoples of the department continued to chew dried coca leaf in keeping with their traditional customs, a practice known as mambeo, which has been inherited from their indigenous ancestors. For them, coca leaf is part of their basic food basket, and they have always cultivated it in small quantities on their small plots. The Statute has no specification in this sense; indigenous people are put at risk that their rights would not be not recognized and their land would be confiscated without any notice (p. 923).

At the end of his speech, Representative Papamija requested that the discussion around the article stay open. His request was rejected, with 83 votes against and 26 in favor. We can draw some conclusions from his statement: the only member of Congress who spoke on the indigenous question was himself from the department that gave rise to the first indigenous-rights organizations. Although Papamijas's attempt to protect the rights of indigenous peoples was rejected, 
26 representatives supported it. The perception of indigenous peoples was clearly undergoing a transformation within the Colombian State, and Article 7 is evidence of the changing approach that state institutions took toward the traditional use of coca leaf by chewing.

International narcotics control institutions have the task of monitoring the implementation of relevant treaties. We have discussed the requests that international organizations have sent to the Colombian government, asking the Colombian State to assure them of its commitment to banning the chewing of coca leaf. Along these lines, we went to the Ministry of Foreign Affairs to request access to the communications that international monitoring institutions sent to the government at the time when Law 30 of 1986 was adopted, and we found that there had been no such communication.

In the absence of any pressure from the international body, the reconstruction of the international norm within Colombian law became a reality.

\section{The 1988 Convention: a wider scope for traditional use}

Twelve countries, including Colombia, Bolivia, and Peru, were the promoters of a proposal "to ensure that the convention did not penalize the licit cultivation of coca bushes and the licit traditional uses of coca leaf" (United Nations, 1988, 296). If the chewing of coca leaf was allowed, however, this would conflict with the principles of the 1961 Convention demanding that controlled substances be used exclusively for medical or scientific purposes. This contradiction was already a concern for a significant number of delegations.

The first and second paragraphs of Article 14 resulted from this debate. They concern "the measures to eradicate illicit cultivation of narcotic plants." Paragraph 2 demands that States consider "fundamental human rights" and "traditional licit uses where there is historic evidence of such use." This paragraph seems to make it possible for native Andean communities to legalize the use of coca leaf while avoiding a conflict with the international law. Nevertheless, the first 
paragraph establishes that any measures taken by virtue of the 1988 Convention must be less restrictive than the provisions of the 1961 Convention.

The 1988 Convention has to be adapted to Colombian society, and Congress submitted an interpretative declaration in which it was established that:

The coca plant cannot be considered in the same way for its legal and legitimate uses and for its use as a raw material to produce cocaine. This differentiation between coca leaf and cocaine is necessary since numerous studies have shown not only that coca leaf could be used in alternative legal trade that could in fact prevent the spread of drug trafficking, but also that the ancestral consumption of coca by our indigenous communities does not have negative effects (C-176/1994, p. 6).

With the entry into force of the 1991 Constitution, every international treaty needed to be approved by the Constitutional Court. Constitutional Court Ruling C-176/1994 expanded on the declaration by Congress, stating that the difference between coca and cocaine in the context of the long-standing traditional uses of coca by native communities conforms to a principle established in the Constitution to the effect that "the State recognizes and protects the ethnic diversity of the Colombian nation".

Even though Colombia expresses its respect for native traditions, the International Narcotics Control Board has announced on several occasions that States must respect their international obligations. To the Board, this means eradicating any use of coca for non-medicinal and nonscientific purposes. Since Article 14 leaves the legal approach to traditional use in a grey zone, the Colombian State continues to be in conflict with international law on drugs. 


\section{Conclusion}

This article has sought to trace the process by which the Colombian State adopted international norms banning the chewing of coca leaf in indigenous communities. In this regard, we noted that the theoretical models provided by the sociology of norms used in this article were mainly useful to understand the precise moment when the norm was adopted, but said less about the process that was followed once the norm was introduced.

We would like to emphasize that our object of study did not take the step of suggesting a new theoretical model for the adoption of a norm, but rather to mobilize elements from among local actors with the aim of understanding how, at a specific time, an international norm could be the object of reconstruction. In the specific case of Colombia and the chewing of coca leaf, the relevant element was its indigenous special jurisdiction.

We should also mention an additional point resulting from our research. Although the history of the norm regarding the chewing of coca leaf by indigenous peoples has evolved in Colombia since the introduction of the 1961 Convention, the State has never asked that the prohibition on chewing coca leaf be amended. Furthermore, Law 13 of 1974 continues to be in force, which leads to a legal conflict within the body of Colombian law. In the absence of pressure from international drug control organizations, however, this legal conflict between norms does not seem to interest anyone. In other words, indigenous groups wish to continue chewing coca leaf, and the government is interested in respecting the rights of indigenous people - rights that are enshrined in the new Constitution. Since the government does not feel pressure on this issue from the international system, the situation remains in a kind of limbo. While the State is complacent now, a new situation will inevitably bring conflict once again in the future.

Some indigenous communities have expressed their intention to use coca leaf to produce tea, cookies, wine, and ointments, and to market them throughout the country. In response, the government has appealed to the 
principle of respect for international treaties, with the goal of banning these products. In addition, the international drug control institutions have publicly opposed any initiative to market coca-based products.

We believe that this new situation broadens the scope of the analysis of the adoption of the international norm on narcotics control. Moreover, the development of a jurisprudence regarding indigenous rights in the international arena with the United Nations Declaration on the Rights of Indigenous Peoples of 2007, the 1989 Indigenous and Tribal Peoples Convention of the International Labour Organization, and domestically and most importantly with the consolidation of the autonomous indigenous jurisdiction, provide more elements to consider when analyzing the administration of conflicting norms within the State. Additional research is therefore essential.

\section{References}

Acharya, A. (2004). How Ideas Spread: Whose Norms Matter? Norm Localization and Institutional Change in Asian Regionalism. International Organization, 58 (2), 2004, 239-275.

Bejarano, J. (1945). El cocaísmo en Colombia. América Indígena, 5 (1), Mexico, 303-310.

Bewley-Taylor, D. (2001). The United States and International Drug Control 1909-1997. New York: Continuum.

Bonilla, G. (2010). El consumo de hojas de coca en el departamento del cauca, Revista de la Universidad Nacional (1944 - 1992), 2, (1945). Revista Trimestral de Cultura Moderna (March-April-May); 426-430.

Borda, C. \& Salalar, J. (September, 1973). Exposición de motivos, (Series Anales del Congreso, Box Ley 13 de 1974), Colección Leyes de la República, Biblioteca del Congreso, Bogotá.

Checkel, J. (1999). Norms, Institutions and National Identity in Contemporary Europe, International Studies Quarterly, 43 (1), 1999, 83-114. Corte Constitucional, Sentencia C-176/94, 1-106.

Cortell, A. \& Davis, J. (1996). How do International Institutions Matter? The Domestic Impact of International Rules and Norms, International Studies Quarterly, 40 (4), 451-478. 
Dudouet, F. (2009). Le Grand deal de l'opium: Histoire du marché légal des drogues, Paris: Éditions Syllepse.

Finnemore, M. (1993). International organizations as teachers of norms: The United Nations Educational, Scientific and Cultural Organization and science policy, International Organizations, 565-597.

García, J. (2007), De la Coca a la cocaina una historia por contar, Bogotá: Universidad del Rosario.

Lande, A. (July 16, 1965). No title (Series Organismos Internacionales, Box 0306, Folder 00053, File 22), Foreign Affairs Minister Collection, Archivos Generales de la Nación, Bogotá.

Lewin, L. (1998). Phantastica: A classic survey on the use and abuse of mind-altering plants, Rochester: Park Street Press, (1924).

Maldonado, J. (March 19, 2008). La coca: el dilema andino. El Espectador. Retrieved from http://www.elespectador.com/impreso/cuadernilloa/ internacional/articuloimpreso-coca-el-dilema-andino

Nadelmann, E. (1990). Global prohibition regimes: the evolution of norms in international society, International Organisation, 44 (4), 479-526.

Nations Unies. (1988). Convention des Nations Unies Contre le Trafic Illicite de Stupéfiants et de Substances Psychotropes, New York.

Nations Unies. (1961). Convention Unique sur les Stupéfiants de 1961, telle que modifiée par le Protocole de 1972 portant amendement de la Convention Unique sur les Stupéfiants de 1961, New York.

Nations Unies. (1950). Rapport de la Commission d'étude sur la feuille de coca, New York.

Papamija, J. (May 23, 1985). No title (Series Anales del Congreso, Box Ley 30 de 1986, File 923). Colección Leyes de la Republica, Biblioteca del Congreso, Bogotá.

Risse, T. \& Sikkink, K. (1999). The socialization of international human rights norms into domestic practices: Introduction, in Risse, T., Ropp, S., Sikkink, K. (Eds.), The Power of Human Rights: International Norms and Domestic Change, Cambridge: Cambridge University Press.

Tellez, C. (November 23, 1965), No title (Series Organismos Internacionales, Box 0306, Folder 00053, File 7-8), Collection of the Ministry of Foreign Affairs, Archivo General de la Nación, Bogotá.

United Nations. (1988). Commentary on the United Nations Convention Against Illicit Traffic in Narcotics Drugs and Pshychotropic Substances, Vienne. 